\title{
Performance of Regularly Cycling Repeater Dairy Cows on Mineral Mixture Supplementation
}

\author{
V. Meenalochani*, D. Chandrasekaran, M. Murugan, M.R. Purusothaman and \\ P. Vasanthakumar \\ Veterinary University Training and Research Centre, TANUVAS, Dharmapuri - 636703, Tamil Nadu.
}

\begin{abstract}
The dairy cows in Dharmapuri district of Tamil Nadu are reared with limited amount of dry fodder, green grass and wheat bran as concentrate sources. This affects the productive and reproductive performance of dairy cows. Hence an attempt was made to assess the deficit per cent of nutrient intake in comparison with NRC (2001) feeding standard, in eight regularly cycling repeater, Jersey cross (Jx) and Holstein Friesian cross (HFx) cows. The results revealed there was deficit / $\mathrm{kg}$ of dry matter intake (DMI) in Total digestible nutrient $(T D N)$, crude protein $(C P)$ and calcium $(C a)$ was The deficit $/ \mathrm{kg}$ of dry matter intake (DMI) in Total digestible nutrient (TDN), crude protein (CP) and calcium (Ca) was $1.65 \mathrm{~kg} /$ day, 1134, 413 and $29 \mathrm{~g} /$ day, respectively and intake of phosphorus was excess by $0.64 \mathrm{~g} /$ day in Jx and in (HFx) cows the DMI,TDN, CP and Ca deficit were $1.26 \mathrm{~kg} /$ day, 865, 394 and $25 \mathrm{~g} /$ day, respectively and intake of phosphorus was excess by $13 \mathrm{~g} /$ day. Considering the low levels of calcium and excess phosphorous intake of the animals when compared to NRC (2001), supplementation of commercially available mineral mixture at the rate of $50 \mathrm{~g}$ per cow per day was done from day of insemination till the days of confirmation of pregnancy (90 days). Even though there was deficiency of other nutrients in this experiment, the trial was planned with mineral mixture alone to ascertain whether feeding mineral mixture alone will be sufficient to mitigate the repeat breeding problems. The result of the study concluded that repeater problem can be nullified to $75 \%$ in Jx cows and 87\% in HFx cows on supplementation of mineral mixture at the rate of $50 \mathrm{gm} /$ day from the day of insemination to 90 days.
\end{abstract}

Keywords: Dairy cows, Deficiency, Nutritional Status, Mineral mixture, Performance

\section{Introduction}

The dairy cows of Dharmapuri district are mostly reared under semi intensive system and were fed with limited amount of cultivated green fodders ( $\mathrm{Co} 4)$, paddy straw or sorghum stover as dry fodder and wheat bran as concentrate feed along with four to five hours of grazing. This leads to nutritional deficiency and affects its reproductive performance. The optimum productive and reproductive efficiency of livestock could be achieved only if the animal receives required quantity of feedstuffs, all nutrients in proper proportion (NRC, 2001) and good management and comfortable environment (Venkatasubramaniam and Fuizele, 1996). Under this feeding managemental condition the animals will not be able to perform to their full genetic potential and leads to heavy economic loss to the farmers. This condition is more prominent with high yielding crossbred dairy cows than the local breeds.

Hence, in the present study an attempt was made to assess the nutritional status of regularly cycling repeater dairy cows and compared with the NRC 2001 nutrient requirement standards. The deficient animals were fed with mineral mixture and the serum biological indicators and its effect on reproductive performance were also studied.

\section{Materials And Methods}

Information about the cropping pattern, livestock holdings and actual feeding of different feed ingredients were collected by direct observations and personal interview with pre-evaluated questionnaire and the intake by animals were calculated. Eight mid lactating dairy cows of second calving, in Jersey cross (Jx) and Holstein Friesian cross (HFx) were selected randomly and weighed. The feed and fodder samples in the study area were collected and analyzed as per AOAC (1995) for dry matter (DMI), crude protein (CP), calcium (Ca) and phosphorous (P) and total digestible nutrients (TDN) values were taken as reported by Ranjhan (1998). Based on the quantity of feed / fodder consumed, the dry matter and nutrient content of feed / fodder, the intake of dry matter and nutrient by the animals were calculated.

The deficit percentage of intake in terms of dry matter (DMI), total digestible nutrient (TDN), crude protein $(\mathrm{CP})$, calcium $(\mathrm{Ca})$ and phosphorus $(\mathrm{P})$ in this study area were compared with the NRC (2001) recommendation in both breeds. The Blood glucose, cholesterol, non-esterified fatty acids are the common metabolites used to assess energy status of cattle (Chester-Jones et al., 1990; Pambu -Gollah et al., 2000; Gruwaldt et al., 2005; Ndlovu et al.,2009). Serum total protein, albumin, globulin, blood urea nitrogen and milk 
urea nitrogen are assessed for protein status. Serum calcium and phosphorus levels are the indicators of macro mineral status (Singh et al., 2008) were quantified with commercial kits as per manufacturer's protocol.

Considering the low level of calcium intake of the animals when compared to NRC (2001) specifications and suboptimum serum calcium level in these animals, supplementation of commercially available mineral mixture preparation containing the following minerals (Table 1) was supplemented at the rate of $50 \mathrm{~g}$ per cow per day from day of insemination to the day of confirmation of pregnancy (70 to 90 days). Even though there was deficiency of other nutrients this experiment was planned with mineral mixture alone, to ascertain whether feeding mineral mixture alone will be sufficient to mitigate the repeat breeding problems.

Table 1Mineral mixture composition

\begin{tabular}{|l|l|l|}
\hline \multicolumn{1}{|c|}{ Minerals } & \multicolumn{1}{|c|}{ Amount (\%) } \\
\hline S.no. & Calcium & 23 \\
\hline 1 & Phosphorus & 12 \\
\hline 2 & Maganese & 6.5 \\
\hline 3 & Iron & 0.5 \\
\hline 4 & Iodine & 0.026 \\
\hline 5 & Copper & 0.077 \\
\hline 6 & Manganese & 0.12 \\
\hline 7 & Cobalt & 0.012 \\
\hline 8 & Zinc & 0.38 \\
\hline 9 & Sulphur & 0.5 \\
\hline 10 & Fluoride & 0.07 \\
\hline 11 & Selenium & $0.3 \mathrm{ppm}$ \\
\hline 12 & & \\
\hline
\end{tabular}

The serum biological indicators were assessed from the date of mineral mixture supplementation at weekly intervals up to the point of confirmation of pregnancy which was carried out between 70 to 90 days post insemination. The data obtained were subjected to statistical analysis as per Snedecor and Cochran (1994) and analysis of variance (ANOVA) and t-test were performed. Further, means were compared using Duncan's multiple range test by using the software package SPSS version 12 (SPSS, 1996).

\section{Results And Discussion}

The deficit $/ \mathrm{kg}$ of dry matter intake (DMI) in Total digestible nutrient (TDN), crude protein (CP) and calcium (Ca) was $1.65 \mathrm{~kg} /$ day, 1134, 413 and $29 \mathrm{~g} /$ day, respectively and intake of phosphorus was excess by $0.64 \mathrm{~g} /$ day in Jx regularly cycling repeater. Similarly, in HFx regularly cycling repeater the DMI,TDN, CP and $\mathrm{Ca}$ deficit was $1.26 \mathrm{~kg} /$ day, 865, 394 and $25 \mathrm{~g} /$ day, respectively and intake of phosphorus was excess by 13 g/day. (Table 2) Even though there was deficiency of other nutrients in this experiment, the trial was planned with mineral mixture alone, as the farmers were adopting the same practice for generations, to ascertain whether feeding mineral mixture alone will be sufficient to mitigate the repeat breeding problems. Considering the low levels of calcium and excess phosphorous intake of the animals when compared to NRC (2001), supplementation of commercially available mineral mixture at the rate of $50 \mathrm{~g}$ per cow per day was done from day of insemination till the days of confirmation of pregnancy (75to 90 days).

The change in serum biochemical parameters related to energy, protein and mineral status were recorded at 15 days interval during the study period ( 0 to 75 days) and shown in Table 3 , Table 4 and Table 5 , respectively for both breeds.

\section{Biological indicators for energy status}

In Jx the glucose varied from 39.18 to $39.23 \mathrm{mg} / \mathrm{dl}$ and in HFx it ranged between 37.87 and $38.87 \mathrm{mg} / \mathrm{dl}$ and was comparable in both breeds. The cholesterol concentration in serum varied from 102.85 to $102.37 \mathrm{mg} / \mathrm{dl}$ in $\mathrm{JX}$ whereas in HFx ranged between 107.37 and $113.64 \mathrm{mg} / \mathrm{dl}$ and was comparable in both breeds.The NEFA value varied between 0.45 and $0.40 \mathrm{mmol} / \mathrm{l}$ in $\mathrm{Jx}$ and in $\mathrm{HFx}$ it ranged between 0.38 and $0.36 \mathrm{mmol} / \mathrm{l}$ and the results were insignificant in both breeds. (Table 3 ).

\section{Biological indicators for protein status}

The total protein concentration in serum varied from 8.18 to $8.33 \mathrm{~g} / \mathrm{dl}$ in $\mathrm{Jx}$ whereas in $\mathrm{HFx}$ it ranged between 8.18 and $8.22 \mathrm{~g} / \mathrm{dl}$ and was comparable in both breeds. The Albumin concentration in serum varied from 3.47 to $3.52 \mathrm{~g} / \mathrm{dl}$ in $\mathrm{Jx}$ whereas in HFx it ranged between 3.81 and $3.97 \mathrm{~g} / \mathrm{dl}$ and was comparable in both breeds. The globulin concentration in serum varied from 4.71 to $4.81 \mathrm{~g} / \mathrm{dl}$ in $\mathrm{Jx}$ whereas in HFx it ranged between 4.37 and $4.25 \mathrm{~g} / \mathrm{dl}$ and was comparable in both breeds. The BUN concentration in serum varied from 12.31 to $12.46 \mathrm{mg} / \mathrm{dl}$ in $\mathrm{Jx}$ whereas in HFx it ranged between 11.55 and $11.82 \mathrm{mg} / \mathrm{dl}$ and was comparable in both breeds. The MUN concentration in milk varied from 8.25 to $8.39 \mathrm{mg} / \mathrm{dl}$ in $\mathrm{Jx}$ whereas in HFx it ranged between 8.41 and $8.55 \mathrm{mg} / \mathrm{dl}$ and was comparable in both breeds. (Table 4). 
The results suggest that there exist no significant difference in serum, glucose, cholesterol and NEFA (energy status), total protein, albumin, globulin, BUN and MUN (protein status) in both breeds. The concentration of biological indicators of energy and protein agreed with findings of Sivaraman (1998) as he stated the values were comparable.

\section{Biological indicators for mineral status}

The calcium concentration in serum linearly increased from 0 to $75^{\text {th }}$ day ( 7.31 to $\left.10.53 \mathrm{mg} / \mathrm{dl}\right)$ in $\mathrm{Jx}$ and the value was significantly increased from thirtieth day of mineral mixture feeding. In HFx it varied between 8.31 and $10.43 \mathrm{mg} / \mathrm{dl}$ and was significantly increased from $45^{\text {th }}$ day of mineral mixture feeding. The phosphorus concentration in serum varied from 3.36 to $4.61 \mathrm{mg} / \mathrm{dl}$ in $\mathrm{JX}$ and the value was significantly increased from $45^{\text {th }}$ day of mineral mixture feeding. In HFx it ranged between 5.24 and $5.52 \mathrm{mg} / \mathrm{dl}$ and was comparable (Table 5). The study revealed that there was significant increase in serum calcium concentration after thirtieth day of feeding mineral mixture in $\mathrm{Jx}_{\mathrm{X}}$ and after forty fifth day in HFx. Similarly, there was significant increase in serum phosphorous after $45^{\text {th }}$ day of feeding in Jx but was comparable in HFx. The result observed was in that of accordance with Nair et al. (1988) in that the calcium level in serum was $8.30 \mathrm{mg} / \mathrm{dl}$ in normal cycling cows and $7.39 \mathrm{mg} / \mathrm{dl}$ in repeat breeders. Similarly, Jayanthi et al. (2003) stated that repeat breeders showed significantly low calcium level $(10.03 \mathrm{mg} / \mathrm{dl}$ in repeaters and $10.95 \mathrm{mg} / \mathrm{dl}$ in normally cycling cows). But the result was in contrary with Madhumeet singh and Pant (1998) who reported the concentration of calcium was $8.24 \mathrm{mg} / \mathrm{dl}$ which did not differ between normal and repeat breeder cows. Further, the result was contrary with the findings of Van Saun (2000), who reported serum concentration of macrominerals are not reflective of dietary status when homeostatic system was functioning properly.

Further, all the animals were examined for pregnancy diagnosis after 90 days of insemination, the conception was confirmed in six animals of JX (75 per cent) and seven animals of HFx (87.5 per cent). The results revealed that though energy and protein deficiency was noticed in repeater cows, the deficiency of minerals affected the conception rate in both breeds. Further, the results agreed with the findings of Johnson et al. (1999) and Tiwary et al. (2010) as they found reproductive problems could be attributed to the deficiency of minerals ( $\mathrm{Ca}$ and $\mathrm{P}$ ) and to overcome this problem, supplementation of minerals with better bioavailability was essential. Bakshi et al. (2012) observed as dairy cows were underfed with respect to macro and micro minerals, and hence farmers should be motivated to supplement mineral mixture in the feed.

\section{Conclusion}

Though the nutritional deficit exist in terms of dry matter intake (DMI) in Total digestible nutrient (TDN), crude protein (CP) and calcium (Ca) as compared to NRC (2001) feeding standards in both Jersey cross and Holstein Friesian cross regularly cycling repeater cows compensating the low levels of calcium and excess phosphorous was met by supplementation of commercially available mineral mixture at the rate of $50 \mathrm{~g}$ per cow per day was done from day of insemination till the days of confirmation of pregnancy (75 -90 days). On rectal examination after 90 days of insemination, pregnancy was confirmed in six animals of Jx (75\%) and seven animals in HFx (87\%) were found pregnant. The results revealed that though energy and protein deficiency was noticed in repeater cows, the deficiency of minerals affected the conception rate in both breeds. This result was similar to the findings of Bakshi and Wadhwa (2011) who reported that repeat breeding in dairy cows can be overcome by feeding mineral mixtures.

\section{Acknowledgement}

The authors are grateful to the Tamil Nadu Veterinary and Animal Sciences University for providing necessary financial assistance for carrying out the research work.

\section{References}

[1]. AOAC, 1995. Official Methods of Analysis, $16^{\text {th }}$ edn. Association of Official Analytical Chemists, Arlington, Virginia, U.SA.

[2]. Bakshi , M.P.S. ,M. Wadhwa and J.S. Hundal, 2012. Nutritional status of animals in periurban dairies in Punjab state. J. Anim. Plant. Sci.,22: 339-343.

[3]. Bakshi, M. P. S. and M. Wadhwa, 2011. Nutritional status of dairy animals in different regions of Punjab state in India. J.Anim. Sci. $81: 52-58$.

[4]. Chester jones.H.,J. P. Fontenot and H. P.Velt, 1990. Physiological and pathological effects of feeding high levels of magnesium to steers.J.Anim.Sci.,68: 4400-4413.

[5]. Grunwaldt, E. G., J. C. Guevara, O. R. Estevez, A. Vicente, Rousselle, H. N. Alcunten, D. Aguerregaray and C. R. Stasi, 2005. Biochemical and Hematological measurements in beef cattle in Mendoza plain range lands(Agerntina).Trop.Anim.Hlth.Prod., 37(6): 527-540.

[6]. Jayanthi, N., M. Cellapandian and S. Balachandran, 2003. Blood biochemical profile of repeat breeding cows in Tirunelveli region of Tamil Nadu, Indian .Vet.J., 80: 939-940.

[7]. Johnson, N. N., P. M. Pepper, R. C. W. Daniel, M. Mc.Gown and W. Fulkerson, 1999.Associations between non-parturient postpartum hypocalcemia and the interval from calving to first ovulation in Holstein Friesian cows. Anim. Sci., 66: $377-383$.

[8]. Madhumeet singh and H.C. Pant. 1998. Blood biochemical profile of normal and repeat breeder cows in Himachal Pradesh. Indian .Vet.J., 19 (2): 156-157. 
[9]. Nair,S.,K, G. Kharche and O.P. Shrivastva,1988.Blood biochemical changes in normal and abnormal cycling crossbred cows. Cheiron., 17:189-191.

[10]. Ndlovu.T., M. Chimonyo, A. I. Okoh, V. Muchenje, K. Dzama, S. Dube and J.G. Raats, 2007. Assessing the nutritional status of beef cattle; current practices and future prospects. African journal of biotechnology. 6: 2727-2734.

[11]. NRC. 2001. Nutrient requirements of dairy cattle. $7^{\text {th }}$ revised ed.,.National Research Council. National Academy Press., Washington, DC.

[12]. Pambu-Gollah, R.P., P. B. Cronje, N.H. Casey, 2000. An evaluation of the use of blood metabolite concentrations as indicators of nutritional status in free ranging goats. S. Afr. J. Anim. Sci., 30: 115-120

[13]. Ranjhan, S.K. 1998. Nutrient requirements of livestock and poultry.Second Revised edn. Indian Council of Agricultural Research. Krishi Anusandhan Bhavan, Pusa, New Delhi.

[14]. Singh, V. K., P. Singh, A. K. Verma and M. R. Mehra, 2008.On farm assessment of lactating cattle and buffaloes in urban , periurban and rural areas of Middle gangetic plains. Liv. Res. Rural Dev., 20: 37-42.

[15]. Snedecor, G.W. and W.G. Cochran, 1994 .Statistical methods .Oxford and I.B.H. publications, New Delhi, India.

[16]. Sivaraman,T., 1998. Application of metabolic profile test in dairy herd health management. Ph.D., Thesis submitted to TANUVAS, Chennai.

[17]. SPSS. 1996. Statistical packages for Social Sciences. Ver.12, SPSS Inc.,Linois, USA.

[18]. Tiwary, M. K. Akhilesh Pandey and Tiwari, D. P, 2010. Mineral status of animals in relation to different physiological stages in Haridwar District of Uttarkhand. Food science and technology., 1: pp 1-9.

[19]. Van Saun, R. J., 2000. Blood profiles as indicators of nutritional status. Advances in dairy technology., 12 : $386-398$.

[20]. Venkatasubramanian,V and R.M. Fuizele, 1996. Factors influencing the production performance of cross bred and indigenous cattle under field conditions. Indian J. Dairy Sci., 49: 301-306.

Table 2 Nutritional status of dairy cows selected for mineral mixture supplement trial

\begin{tabular}{|l|l|l|l|l|l|l|l|l|l|l|l|l|l|l|l|}
\hline Breed & \multicolumn{3}{|c|}{ DMI (kg/day) } & \multicolumn{3}{c|}{ TDN(g/day) } & \multicolumn{3}{c|}{ CP (g/day) } & \multicolumn{3}{c|}{ Calcium (g/day) } & \multicolumn{2}{c|}{ Phosphorus (g/day) } \\
\hline & Rec & Fed & Deficit & Rec & Fed & Deficit & Rec & Fed & Deficit & Rec & Fed & Deficit & Rec & Fed & Excess \\
\hline $\mathbf{J x}$ & $\begin{array}{l}9.18 \\
\pm 0.21\end{array}$ & $\begin{array}{l}7.53 \\
\pm 0.10\end{array}$ & $\begin{array}{l}1.65 \\
\pm 0.18\end{array}$ & $\begin{array}{l}6111 \\
\pm 839\end{array}$ & $\begin{array}{l}4977 \\
\pm 974\end{array}$ & $\begin{array}{l}1134 \\
\pm 865\end{array}$ & $\begin{array}{l}1143 \\
\pm 271\end{array}$ & $\begin{array}{l}730 \\
\pm 277\end{array}$ & $\begin{array}{l}413 \\
\pm 194\end{array}$ & $\begin{array}{l}48.67 \\
\pm 9.23\end{array}$ & $\begin{array}{l}19.54 \\
\pm 8.23\end{array}$ & $\begin{array}{l}29.13 \\
\pm 6.78\end{array}$ & $\begin{array}{l}20.98 \\
\pm 5.64\end{array}$ & $\begin{array}{l}21.62 \\
\pm 8.79\end{array}$ & $\begin{array}{l}+0.64 \\
\pm 3.76\end{array}$ \\
\hline $\mathbf{H F x}$ & $\begin{array}{l}10.41 \\
\pm 0.25\end{array}$ & $\begin{array}{l}9.15 \\
\pm 0.21\end{array}$ & $\begin{array}{l}1.26 \\
\pm 0.15\end{array}$ & $\begin{array}{l}6839 \\
\pm 640\end{array}$ & $\begin{array}{l}5974 \\
\pm 520\end{array}$ & $\begin{array}{l}865 \\
\pm 280\end{array}$ & $\begin{array}{l}1271 \\
\pm 252\end{array}$ & $\begin{array}{l}877 \\
\pm 334\end{array}$ & $\begin{array}{l}394 \\
\pm 112\end{array}$ & $\begin{array}{l}58.65 \\
\pm 2.5\end{array}$ & $\begin{array}{l}24.96 \\
\pm 6.21\end{array}$ & $\begin{array}{l}25.23 \\
\pm 4.25\end{array}$ & $\begin{array}{l}24.34 \\
\pm 3.37\end{array}$ & $\begin{array}{l}37.44 \\
\pm 2.37\end{array}$ & $\begin{array}{l}13.1 \\
\pm 2.12\end{array}$ \\
\hline
\end{tabular}

Rec-Recommended

Table -3 Effect of mineral mixture on biological indicators for energy status in dairy cows

\begin{tabular}{|c|c|c|c|c|c|c|c|}
\hline $\begin{array}{l}\text { Energy } \\
\text { parameters }\end{array}$ & Breed & 0 day & $15^{\text {th }}$ day & $30^{\text {th }}$ day & $4^{\text {th }}$ day & $60^{\text {th }}$ day & $75^{\text {th }}$ day \\
\hline \multirow{2}{*}{$\begin{array}{l}\text { Glucose } \\
(\mathrm{mg} / \mathrm{dl})\end{array}$} & Jersey crossbred & $39.18 \pm 0.05$ & $39.24 \pm 0.05$ & $39.21 \pm 0.06$ & $39.25 \pm 0.66$ & $39.15 \pm 0.05$ & $39.23 \pm 0.08$ \\
\hline & $\begin{array}{l}\text { Holstein Friesian cross } \\
\text { bred }\end{array}$ & $37.87 \pm 0.28$ & $37.85 \pm 0.29$ & $38.41 \pm 0.39$ & $38.54 \pm 0.69$ & $38.63 \pm 0.57$ & $38.87 \pm 0.54$ \\
\hline \multirow{2}{*}{$\begin{array}{l}\text { Cholesterol } \\
(\mathrm{mg} / \mathrm{dl})\end{array}$} & Jersey crossbred & $102.85 \pm 1.58$ & $102.97 \pm 1.50$ & $102.03 \pm 1.70$ & $102.15 \pm 1.64$ & $102.43 \pm 1.62$ & $102.37 \pm 2.73$ \\
\hline & $\begin{array}{l}\text { Holstein Friesian cross } \\
\text { bred }\end{array}$ & $107.37 \pm 3.89$ & $108.63 \pm 4.50$ & $11.00 \pm 2.47$ & $111.04 \pm 2.57$ & $113.62 \pm 2.28$ & $113.64 \pm 2.29$ \\
\hline \multirow{2}{*}{$\begin{array}{l}\text { NEFA } \\
(\mathrm{mmol} / \mathrm{l})\end{array}$} & Jersey crossbred & $0.45 \pm 0.01$ & $0.42 \pm 0.02$ & $0.40 \pm 0.04$ & $0.45 \pm 0.01$ & $0.42 \pm 0.02$ & $0.40 \pm 0.04$ \\
\hline & $\begin{array}{l}\text { Holstein Friesian cross } \\
\text { bred }\end{array}$ & $0.38 \pm 0.09$ & $0.37 \pm 0.03$ & $0.38 \pm 0.02$ & $0.37 \pm 0.06$ & $0.37 \pm 0.06$ & $0.36 \pm 0.08$ \\
\hline
\end{tabular}

Means in a row with at least one common superscript do not differ significantly $(\mathrm{P}<0.05)$

Table 4 Effect of mineral mixture on biological indicators for protein status in dairy cows

\begin{tabular}{|l|l|c|c|c|c|c|c|}
\hline \multicolumn{1}{|c}{$\begin{array}{c}\text { Protein } \\
\text { parameters }\end{array}$} & \multicolumn{1}{|c|}{ Breed } & $\mathbf{0}$ day & $\mathbf{1 5}^{\text {th }} \mathbf{d a y}$ & $\mathbf{3 0}^{\text {th }} \mathbf{d a y}$ & $\mathbf{4 5}^{\text {th }} \mathbf{d a y}$ & $\mathbf{6 0}^{\text {th }} \mathbf{d a y}$ & $\mathbf{7 5}^{\text {th }} \mathbf{d a y}$ \\
\hline \multirow{2}{*}{ Total protein $(\mathrm{g} / \mathrm{dl})$} & Jersey crossbred & $8.18 \pm 0.01$ & $8.23 \pm 0.04$ & $8.29 \pm 0.05$ & $8.23 \pm 0.04$ & $8.31 \pm 0.09$ & $8.33 \pm 0.09$ \\
\cline { 2 - 8 } & $\begin{array}{l}\text { Holstein Friesian } \\
\text { crossbred }\end{array}$ & $8.18 \pm 0.01$ & $8.21 \pm 0.05$ & $8.19 \pm 0.02$ & $8.26 \pm 0.04$ & $8.21 \pm 0.02$ & $8.22 \pm 0.04$ \\
\hline $\begin{array}{l}\text { Albumin } \\
(\mathrm{g} / \mathrm{dl})\end{array}$ & Jersey crossbred & $3.47 \pm 0.12$ & $3.55 \pm 0.11$ & $3.55 \pm 0.17$ & $3.50 \pm 0.11$ & $3.55 \pm 0.12$ & $3.52 \pm 0.13$ \\
\cline { 2 - 8 } & $\begin{array}{l}\text { Holstein Friesian } \\
\text { crossbred }\end{array}$ & $3.81 \pm 0.01$ & $3.79 \pm 0.01$ & $3.84 \pm 0.03$ & $3.86 \pm 0.03$ & $3.90 \pm 0.02$ & $3.97 \pm 0.14$ \\
\hline $\begin{array}{l}\text { Globulin } \\
(\mathrm{g} / \mathrm{dl})\end{array}$ & Jersey crossbred & $4.71 \pm 0.12$ & $4.67 \pm 0.15$ & $4.74 \pm 0.20$ & $4.73 \pm 0.14$ & $4.76 \pm 0.11$ & $4.81 \pm 0.19$ \\
\cline { 2 - 8 } & $\begin{array}{l}\text { Holstein Friesian } \\
\text { crossbred }\end{array}$ & $4.37 \pm 0.02$ & $4.41 \pm 0.05$ & $4.35 \pm 0.04$ & $4.39 \pm 0.05$ & $4.31 \pm 0.04$ & $4.25 \pm 0.15$ \\
\hline \multirow{2}{*}{$\begin{array}{l}\text { BUN } \\
(\mathrm{mg} / \mathrm{dl})\end{array}$} & Jersey crossbred & $12.31 \pm 0.01$ & $12.39 \pm 0.03$ & $12.40 \pm 0.07$ & $12.47 \pm 0.11$ & $12.46 \pm 0.11$ & $12.46 \pm 0.08$ \\
\cline { 2 - 8 } & $\begin{array}{l}\text { Holstein Friesian } \\
\text { crossbred }\end{array}$ & $11.55 \pm 0.08$ & $11.46 \pm 0.11$ & $11.48 \pm 0.11$ & $11.49 \pm 0.10$ & $11.62 \pm 0.10$ & $11.82 \pm 0.23$ \\
\hline $\begin{array}{l}\text { MUN } \\
\text { (mg/dl) }\end{array}$ & Jersey crossbred & $8.25 \pm 0.01$ & $8.27 \pm 0.02$ & $8.28 \pm 0.02$ & $8.37 \pm 0.07$ & $8.36 \pm 0.09$ & $8.39 \pm 0.06$ \\
\cline { 2 - 7 } & $\begin{array}{l}\text { Holstein Friesian } \\
\text { crossbred }\end{array}$ & $8.41 \pm 0.05$ & $8.41 \pm 0.04$ & $8.45 \pm 0.05$ & $8.46 \pm 0.04$ & $8.52 \pm 0.05$ & $8.55 \pm 0.05$ \\
\hline
\end{tabular}

Means in a row with at least one common superscript do not differ significantly $(\mathrm{P}<0.05)$

DOI: 10.9790/2380-1004010913 www.iosrjournals.org 


\section{Performance of Regularly Cycling Repeater Dairy Cows on Mineral Mixture Supplementation}

Table 5 Effect of mineral mixture on biological indicators for mineral status in dairy cows

\begin{tabular}{|l|l|c|c|c|c|c|c|}
\hline \multicolumn{1}{c}{$\begin{array}{c}\text { Mineral } \\
\text { parameters }\end{array}$} & \multicolumn{1}{|c|}{ Breed } & $\mathbf{0}$ day & $\mathbf{1 5}^{\text {th }} \mathbf{d a y}$ & $\mathbf{3 0}^{\text {th }} \mathbf{d a y}$ & $\mathbf{4 5}^{\text {th }} \mathbf{d a y}$ & $\mathbf{6 0}^{\text {th }} \mathbf{d a y}$ & $\mathbf{7 5}^{\text {th }} \mathbf{d a y}$ \\
\hline \multirow{2}{*}{ Calcium (mg/dl) } & Jersey crossbred & $7.31^{\mathrm{d}} \pm 0.06$ & $7.35^{\mathrm{d}} \pm 0.04$ & $8.57^{\mathrm{c}} \pm 0.10$ & $9.24^{\mathrm{d}} \pm 0.19$ & $10.16^{\mathrm{a}} \pm 0.13$ & $10.53^{\mathrm{a}} \pm 0.17$ \\
\cline { 2 - 7 } & $\begin{array}{l}\text { Holstein Friesian } \\
\text { crossbred }\end{array}$ & $8.31^{\mathrm{c}} \pm 0.06$ & $8.35^{\mathrm{c}} \pm 0.04$ & $8.57^{\mathrm{c}} \pm 0.10$ & $9.48^{\mathrm{b}} \pm 0.20$ & $10.16^{\mathrm{a}} \pm 0.13$ & $10.43^{\mathrm{a}} \pm 0.03$ \\
\hline \multirow{2}{*}{$\begin{array}{l}\text { Phosphorus } \\
(\mathrm{mg} / \mathrm{dl})\end{array}$} & Jersey crossbred & $3.36^{\mathrm{b}} \pm 0.09$ & $3.49^{\mathrm{b}} \pm 0.09$ & $3.48^{\mathrm{b}} \pm 0.05$ & $4.47^{\mathrm{a}} \pm 0.08$ & $4.51^{\mathrm{a}} \pm 0.08$ & $4.61^{\mathrm{a}} \pm 0.09$ \\
\cline { 2 - 8 } & $\begin{array}{l}\text { Holstein Friesian } \\
\text { crossbred }\end{array}$ & $5.24 \pm 0.05$ & $5.36 \pm 0.08$ & $5.48 \pm 0.05$ & $5.38 \pm 0.18$ & $5.47 \pm 0.08$ & $5.52 \pm 0.09$ \\
\hline
\end{tabular}

Means in a row with at least one common superscript do not differ significantly $(\mathrm{P}<0.05)$ 